PREPARED IN PART IN COOPERATION WITH THE COMMONWEALTH OF MASSACHUSETTS

DEPARTMENT OF PUBLIC WORKS

\title{
AEROMAGNETIC MAP OF THE PEPPERELL QUADRANGLE, MIDDLESEX COUNTY, MASSACHUSETTS, AND HILLSBOROUGH COUNTY, NEW HAMPSHIRE
}

\author{
GEOPHYSICAL INVESTIGATIONS \\ MAP GP-732
}

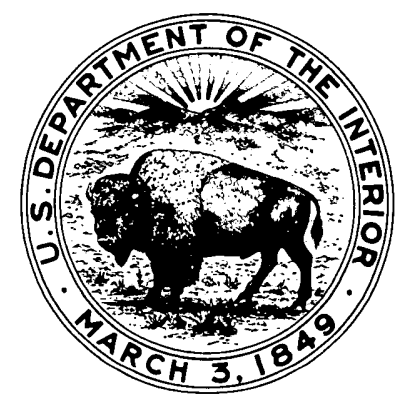

